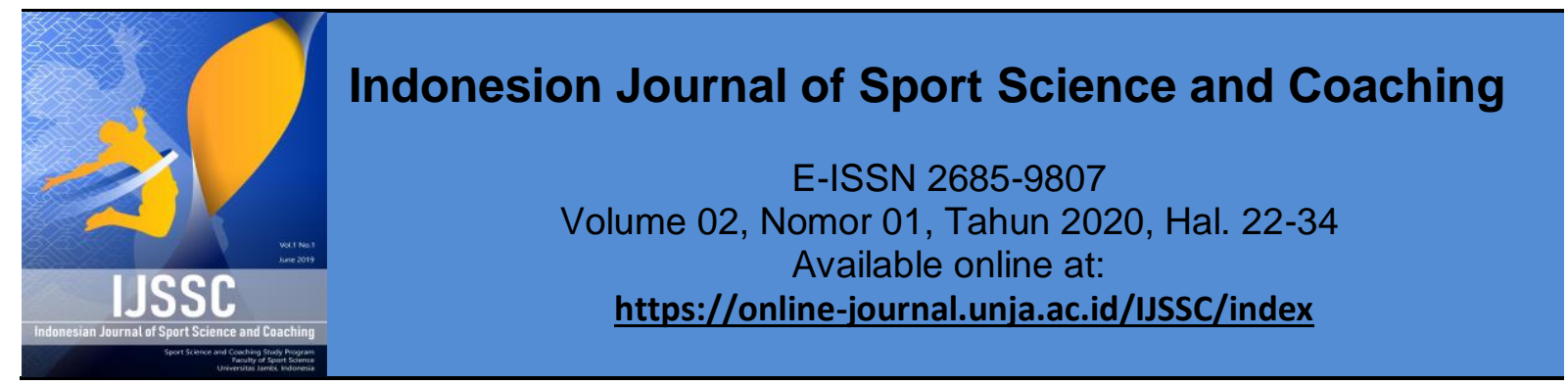

Research Article OPEN ACCESS

\title{
Pengaruh Media Piramida Terhadap Kemampuan Teknik Dasar Tendangan Lurus Pada Materi Bela Diri Pencak Silat
}

\author{
(The Influence of Pyramid Media on the Basic Technical Capabilities of a Straight Kick on \\ Pencak Silat Self-Defense Material)
}

\author{
Ria Ismawati ${ }^{*}$, Widati Amalin Ulfah, M. Rizkan Khadavi \\ Jurusan Pendidikan Jasmani Kesehatan dan Rekreasi \\ STKIP Muhammadiyah Bangka Belitung, Jalan K H Ahmad Dahlan KM 4, RT.03 No. 51 \\ Kelurahan Mangkol Kecamatan, Pangkalan Baru Kab. Bangka Tengah \\ Provinsi Kepulauan Bangka Belitung - Indonesia \\ ${ }^{*}$ Corresponding author: riaismawati18@gmail.com
}

\begin{tabular}{|c|c|}
\hline Informasi Artikel & ABSTRACT \\
\hline $\begin{array}{l}\text { Submit: } 07-10-2019 \\
\text { Diterima: } 03-02-2020 \\
\text { Dipublikasikan: } 19-02-2020\end{array}$ & $\begin{array}{l}\text { This research is motivated by the students' skills in one of the } \\
\text { basic techniques in a straight kick which is not good, especially } \\
\text { when implementing a straight kick. This study applies the use of } \\
\text { pyramid media which aims to determine the effect of the pyramid } \\
\text { media on the ability of the basic technique of a straight kick on } \\
\text { martial arts martial arts class VII students of SMP Negeri } 2 \\
\text { Pangkalpinang. This research uses a quantitative approach with } \\
\text { pre-experimental methods. The design used is one group pretest- } \\
\text { posttest design. The population of the study was } 262 \text { students of } \\
\text { SMP Negeri } 2 \text { Pangkalpinang with } 262 \text { students while the } \\
\text { sampling technique was cluster random sampling, the sample in } \\
\text { this study was } 33 \text { students. The data analysis technique of this } \\
\text { study used a normality test with a pretest value of } 0.234 \text { and a } \\
\text { posttest value of } 0.126 \text { while a Dtable value of } 0.2077 . \text { Of the two } \\
\text { groups of data has a value } \leq \text { Dtable so that both groups of data } \\
\text { are said to be normally distributed while the homogeneity test is } \\
\text { obtained Fcount } 1.27<\text { Ftable1.80 then the data has a } \\
\text { homogeneous variant and the T test for the hypothesis test there } \\
\text { is an increase of } 42 \% \text {, then seen from the results of tcount } \\
18,173>\text { table } 2.0423 \text { with a significance level of } 0.05 \% \text { which } \\
\text { means that Ho was rejected and Ha was accepted. Then it can be } \\
\text { stated that there is an influence of the pyramid media on the ability } \\
\text { of the basic technique of a straight kick on martial arts martial arts } \\
\text { class VII graders of SMP Negeri } 2 \text { Pangkalpinang. } \\
\text { Key words: Media, Pyramid, Ability, Straight Kick. }\end{array}$ \\
\hline Penerbit & ABSTRAK \\
\hline $\begin{array}{l}\text { Jurusan Pendidikan Olah Raga dan } \\
\text { Kepelatihan FKIP Universitas Jambi } \\
\text { Jambi- Indonesia }\end{array}$ & $\begin{array}{l}\text { Penelitian ini dilatar belakangi oleh keterampilan siswa pada salah } \\
\text { satu teknik dasar dalam tendangan lurus yang kurang baik } \\
\text { terutama pada saat pelaksanaan tendangan lurus. Penelitian ini } \\
\text { menerapkan penggunaan media piramida yang bertujuan untuk } \\
\text { mengetahui pengaruh media piramida terhadap kemampuan } \\
\text { teknik dasar tendangan lurus pada materi bela diri pencak silat } \\
\text { siswa kelas VII SMP Negeri } 2 \text { Pangkalpinang. Penelitian ini } \\
\text { menggunakan pendekatan kuantitatif dengan metode pre- } \\
\text { experimental. Desain yang di gunakan yatiu one group pretest- } \\
\text { postest design. Populasi penelitian ini adalah siswa kelas VII SMP }\end{array}$ \\
\hline
\end{tabular}


Negeri 2 Pangkalpinang sebanyak 262 siswa sedangkan teknik pengambilan sampel dengan teknik kluster random sampling, sampel pada penelitian ini berjumlah 33 siswa. Teknik analisis data penelitian ini menggunakan uji normalitas dengan nilai pretest $D_{\text {hituna }} 0,234$ dan posttest $D_{\text {hituna }} 0,126$ sedangkan nilai $D_{\text {tabel }} 0,2077$. Dari kedua kelompok data memiliki nilai $\leq D_{\text {tabel }}$ sehingga kedua kelompok data tersebut dikatakan berdistribusi normal sedangkan uji homogenitas diperoleh nilai $F_{\text {hituno }}$ $1.27<\mathrm{F}_{\text {tabel }} 1.80$ maka data memiliki varian yang homogen dan uji $\mathrm{T}$ untuk uji hipotesis terdapat peningkatan sebesar $42 \%$, kemudian dilihat dari hasil $t_{\text {hitung }} 18,173>t_{\text {tabel }} 2.0423$ dengan taraf signifikan $0,05 \%$ yang berarti $\mathrm{H}_{0}$ ditolak dan $\mathrm{H}_{\mathrm{a}}$ diterima. Maka dapat dinyatakan bahwa terdapat pengaruh media piramida terhadap kemampuan teknik dasar tendangan lurus pada materi bela diri pencak silat siswa kelas VII SMP Negeri 2 Pangkalpinang. Kata kunci: Media, Piramida, Kemampuan, Tendangan Lurus.

This Indonesian Journal of Sport Science and Coaching is licensed under a CC BY-NC-SA (Creative Commons Attribution-ShareAlike 4.0 International License)

\section{PENDAHULUAN}

Pendidikan jasmani dan pendidikan olahraga adalah dua macam pendidikan yang saling berhubungan terhadap dunia pendidikan sehingga pada saat ini nama dari pendidikan tersebut telah berubah menjadi pendidikan jasmani, kesehatan dan olahraga atau disingkat PJOK. Dua macam pendidikan yang digabung menjadi satu ini sangat berperan aktif terhadap dunia pendidikan yang ada di sekolah (Bangun, S. Y.,2016). Hal tersebut dilihat dari beberapa manfaat dan kegunaan dalam pembelajaran PJOK yang tidak hanya mengembangkan wawasan intelektual dan sosial para siswa, melainkan juga membangun mental dan spiritual para siswa (Royana, I. F.,2017). Ada banyak materi pembelajaran yang ada dalam mata pelajaran PJOK di sekolah, salah satunya materi pencak silat. Pembelajaran pencak silat perlu diajarkan kepada para siswa baik untuk mengenal tentang sejarah berdirinya pencak silat, mengenal macam-macam perguruan pencak silat yang ada di Indonesia dan mengenal beberapa teknik dasar dalam pencak silat.

Pembelajaran pencak silat telah berkembang ditingkat sekolah dasar, sekolah menengah pertama dan sekolah menengah atas. Dalam silabus sekolah menengah pertama materi bela diri pencak silat terdapat didalam silabus, sehingga materi tersebut diajarkan kepada siswa. Pembelajaran bela diri pencak silat dilakukan selama 3 jam pelajaran dalam satu kali pertemuan, untuk satu jam pertamasiswamembaca materi pencak silat sedangkan untuk jam kedua dan ketiga siswa praktik. Berdasarkan Kompetensi Dasar yang tercantum didalam silabus PJOK kelas VII bahwa siswa dapat memahami konsep gerak spesifik seni bela diri dan siswa dapat mempraktikan teknik gerak spesifik seni bela diri. Materi menyangkut tendangan, pukulan, elakan dan belaan. Teknik-teknik tersebut merupakan materi yang akan diajarkan, salah satunya teknik tendangan lurus, tendangan lurus merupakan tendangan yang dilakukan kearah depan dengan menggunakan jari-jari bagian dalam. 
Tendangan lurus menjadi andalan para atlet dalam pertandingan karena selain mudah dilakukan tendangan ini juga sulit ditangkap oleh lawan tendangan merupakan teknik yang cukup tinggi dalam penilaian sebuah pertandingan (Nugraha, B. E., 2014). Tendangan lurus juga sangat efektif untuk menghasilkan power tendangan yang lebih besar karena lintasannya yang kedepan bagus untuk mendorong lawan sampai lawan terjatuh (Filipus, W.,2019). Pada materi pencak silat, pemahaman peserta didik hanya dalam bentuk teori, sedangkan untuk praktik teknik dasar tendangan lurus siswa masih belum maksimal serta guru tidak menggunakan pengembangan media sehingga menjadi hambatan dalam pembelajaran (Ihsan, N., \& Suwirman, S.,2018).

Berdasarkan hasil observasi yang dilakukan pada pra penelitian terhadap siswa kelas VII SMP Negeri 2 Pangkalpinang pada tanggal 04 April 2019, menunjukan bahwa pelaksanaan tendangan yang dilakukan oleh siswa masih belum maksimal, hal ini terlihat dari sikap pelaksanaan tendangan lurus dimana tendangan yang dihasilkan masih rendah sehingga tidak mencapai target sasaran, sasaran dalam tendangan lurus yaitu dada/ulu hati dan dagu, kemudian saat menendang perkenaan kaki siswa bukan menggunakan ujung jari-jari bagian dalam melainkan siswa menggunakan sisi bagian luar telapak kaki.Berdasarkan hasil wawancara peneliti dengan guru PJOK SMP Negeri 2 Pangkalpinang pada tanggal 05 April 2019 bahwa siswa yang dapat melakukan teknik dasar tendangan lurus dengan benar hanya berjumlah 11 orang dari 33 siswa. Terdiridari 7 orang laki-lakidan 4 orang perempuan. Hal ini dikarenakan masih kurangnya kreativitas guru dalam memanfaatkan media lain untuk menunjang kemampuan teknik dasar tendangan lurus, karena saat mengajar guru hanya menggunakan media peaching. Mengatasi hal ini, maka untuk meningkatkan kemampuan teknik dasar tendangan lurus pada materi bela diri pencak silat siswa kelas VII SMP Negeri 2 Pangkalpinang. Peneliti memberikan solusi pembelajaran yang menggunakan media piramida. Media ini digunakan sebagai alat bantu siswa sebagai penghalang agar tungkai kaki siswa saat menendang lurus dapat maksimal. Media piramida diharapkan dapat meningkatkan kemampuan teknik dasar tendangan lurus siswa.

Media piramida merupakan alat sederhana yang terbuat dari kardus yang terdiri dari 4 kardus, setiap kardus diberi warna yang berbeda-beda dan dibuat semenarik mungkin (Wilujeng, F., 2011).. Keseluruhan tingkatan kardus memiliki ukuran dengan tinggi $97 \mathrm{~cm}$ dan berat keseluruhan kardus $1 / 2 \mathrm{~kg}$, namun dalam pelaksanaan tinggi tingkatan kardus disesuaikan dengan ukuran siswa karna setiap siswa memiliki tinggi yang berbeda-beda. Untuk tingkatan pertama dengan tinggi kardus $27 \mathrm{~cm}$, lebar $69 \mathrm{~cm}$ dan berat 2 ons, tingkatan kedua dengan tinggi kardus $26 \mathrm{~cm}$, lebar $56 \mathrm{~cm}$ dan berat $1 \frac{1}{2} \mathrm{ons}$, tingkatan ketiga dengan ukuran tinggi kardus $25 \mathrm{~cm}$, lebar $33 \mathrm{~cm}$ dan berat kardus 1 ons dan untuk tingkatan keempat dengan tinggi kardus $20 \mathrm{~cm}$, lebar $20 \mathrm{~cm}$ dan berat $1 / 2$ ons (Andari, M. S.,2014; Yuliantika, S.,2017) 


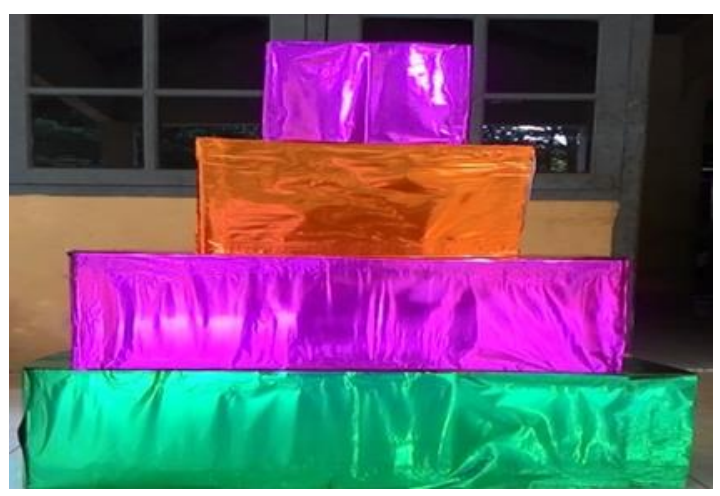

Gambar 1. Media Piramida

\section{METODE PENELITIAN}

Metode penelitian yang digunakan adalah jenis penelitian Pre-eksperimental design, dengan menggunakan desain one group pretest posttest design karena penulis akan memberikan pretest $\left(O_{1}\right)$ Terlebih dahulu, setelah melakukan pretest siswa diberikan tindakan menggunakan media piramida untuk meningkatkan kemampuan teknik dasar tendangan lurus, setelah diberikan perlakuan tersebut siswa akan diberikan tes akhir $\left(O_{2}\right)$. Sugiyono (2017: 74) pada desain ini terdapat pretest, sebelum diberi perlakuan. Dengan demikian hasil perlakuan dapat diketahui lebih akurat, karena dapat membandingkan dengan keadaan sebelum diberi perlakuan. Adapun desain dari penelitian ini dapat dilihat pada gambar 2.

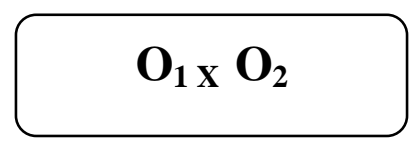

Gambar 2. Design penelitian (Sugiyono.,2017:74)

Keterangan:

$\mathrm{O}_{1}=$ nilai pretest (sebelum diberi diklat/perlakuan)

$\mathrm{O}_{2}=$ nilai posttest (setelah diberi dikla t/perlakuan)

$\mathrm{X}=$ perlakuan

Pengaruh diklat/perlakuan terhadap pemahaman siswa $=\left(\mathrm{O}_{2}-\mathrm{O}_{1}\right)$.

Dalam penelitian ini ada 2 variabel, yaitu:

1. Variabel Independen: dalam bahasa indonesia yaitu variabel bebas atau seringdisebut juga dengan variabel $(\mathrm{X})$, dalam penelitian ini yang menjadi variabel bebas adalah media Piramida.

2. Variabel Dependen: dalam bahasa indonesia yaitu variabel terikat atau sering disebut juga dengan variabel $(\mathrm{Y})$, dalam penelitian ini yang menjadi variabel terikat adalah kemampuan teknik dasar tendangan lurus pencak silat siswa kelas VII SMP Negeri 2 Pangkalpinang. 
Penelitian ini dilaksanakan di SMP Negeri 2 Pangkalpinang Jl. Adhyaksa 181 Pangkalpinan. Pelaksanaan penelitian ini akan dilakukan sebanyak 4 kali pertemuan (1 pertemuan dengan rincian waktu $3 \times 40$ menit) dengan jadwal dipertemuan pertama akan dilaksanakan pretest dan selanjutnya akan diberi perlakuan pada pertemua X 100 jutnya setelah diberi perlakuan dengan media piramida selanjutnya akan dilakukan posttest dengan tujuan untuk mengetahui bagaimana pengaruh media Piramida terhadap kemampuan teknik dasar tendangan lurus pencak silat.Populasi dalam penelitian ini adalah seluruh siswa kelas VII SMP Negeri 2 Pangkalpinang Kota Pangkalpinang Provinsi Kep. Bangka Belitung yang berjumlah 262 orang. Menurut Sugiyono (2017: 81) "Sampel adalah bagian dari jumlah dan karakteristik yang dimiliki oleh populasi tersebut". Dalam penelitian ini teknik pengambilan sampel yang digunakan adalah teknik kluster random sampling. Sampel yang terpilih pada penelitian ini ialah kelas VII/C yang berjumlah 33 orang siswa dalam satu kelas yang terdiri dari 17 siswa laki-laki dan 16 siswa perempuan. Teknik pengumpulan data dalam penelitian ini menggunakan tes teknik dasar tendangan lurus pencak silat.

$$
\text { Nilai }=\frac{\text { Jumlah Skor Perolehan }}{\text { Skor Maksimal }}
$$

Dalam penelitian perhitungan validitas data menggunakan validitas konstruk dengan menggunakan pendapat para ahli (judgment experts). Reliabilitas alat ukur adalah ketepatan alat tersebut mengukur apa yang diuk urnya, dalam penelitian ini perhitungan reliablilitas instrumen menggunakan metode Tes-Retest (tes ulang). Dalam metode Tes-Rest pengujian (uji coba) dilakukan dua kali terhadap sampel yang sama. Untuk pengujian ini menggunakan rumus.

$$
r=\frac{\mathrm{n}\left(\sum \mathrm{xy}\right)-\left(\sum \mathrm{x}\right)\left(\sum \mathrm{y}\right)}{\sqrt{\left[\mathrm{n}\left(\sum x^{2}\right)-\left(\sum x\right)^{2}\right]\left[\mathrm{n}\left(\sum y^{2}-\left(\sum y\right)^{2}\right)\right]}}
$$

Gambar 3. Rumus Product Moment (Sugiyono, 2017: 205)

Keterangan :

$X \quad=$ skor pengamatan pertama

$\mathrm{Y}=$ skor pengamatan kedua

$\mathrm{N}=$ jumlah responden

$\Sigma \quad=$ Jumlah skor variabel $\mathrm{X}$

$\sum y=$ Jumlah skor variabel $Y$

$\sum x y=$ Jumlah total data $X Y$

Sugiyono (2017: 147) menyatakan dalam penelitian kuantitaif, analisis data merupakan kegiatan setelah data dari responden atau sumber data lain terkumpul. Uji normalitas bertujuan untuk mengetahui apakah distribusi datanya menyimpang atau tidak dari distribusi normal. Pada penelitian ini uji normalitas menggunakan uji kolmogrov-smirnov. 
Untuk menguji homogenitas digunakan rumus perbandingan varian dapat dilihat pada gambar 4 .

$$
F=\frac{S^{2} \text { terbesar }}{S^{2} \text { terkecil }}
$$

Gambar 4. Rumus Perbandingan varian (Riadi, 2014: 104)

Keterangan :

$\mathrm{S}^{2}$ terbesar $=$ varian terbesar

$\mathrm{S}^{2}$ terkecil = varian terkecil

Menguji hipotesis yang digunakan $\mathrm{Uji}$ t. Rumus pengujian hipotesismenggunakan rumus $U \mathrm{ji} T(t-t e s t)$ dengan taraf signifikan $=0,05$. Adapun rumus yang digunakan pada gambar 5 .

$$
\mathrm{t}=\frac{\sum D}{\sqrt{\frac{\left(N \cdot \sum D^{2}\right)-\left(\sum D\right)^{2}}{N-1}}}
$$

Gambar 5. Rumus Rumus Uji t-test (Riadi, 2014: 157)

Keterangan:

$\mathrm{t}=$ Nilai $\mathrm{t}$

$\mathrm{D}=$ Perbedaan setiap pasangan skor (pretest-postest)

$\mathrm{N}=$ Jumlah Sampel

\section{HASIL PENELITIAN DAN PEMBAHASAN}

\section{Deskripsi Data}

a. Kemampuan teknik dasar tendangan lurus saat pretest.

Tabel 1. Deskripsi Data Pretest

\begin{tabular}{cc}
\hline $\mathrm{N}$ & 33 \\
\hline Mean & 45.51 \\
Median & 58 \\
Std. Deviation & 15,62 \\
Variance & 243.98 \\
Minimum & 25 \\
Maximum & 92 \\
\hline
\end{tabular}

Hasil perhitungan dari data tes kemampuan teknik dasar tendangan lurus siswa kelas VII SMP Negeri 2 Pangkalpinang saat pretest diperoleh hasil data Mean 45.51, Median 58, Std.Deviation 15,62, Variance 243,98, Minimum 25, Maksimum 92. 
Vol. 02, No. 01 (2020), Hal. 22-34

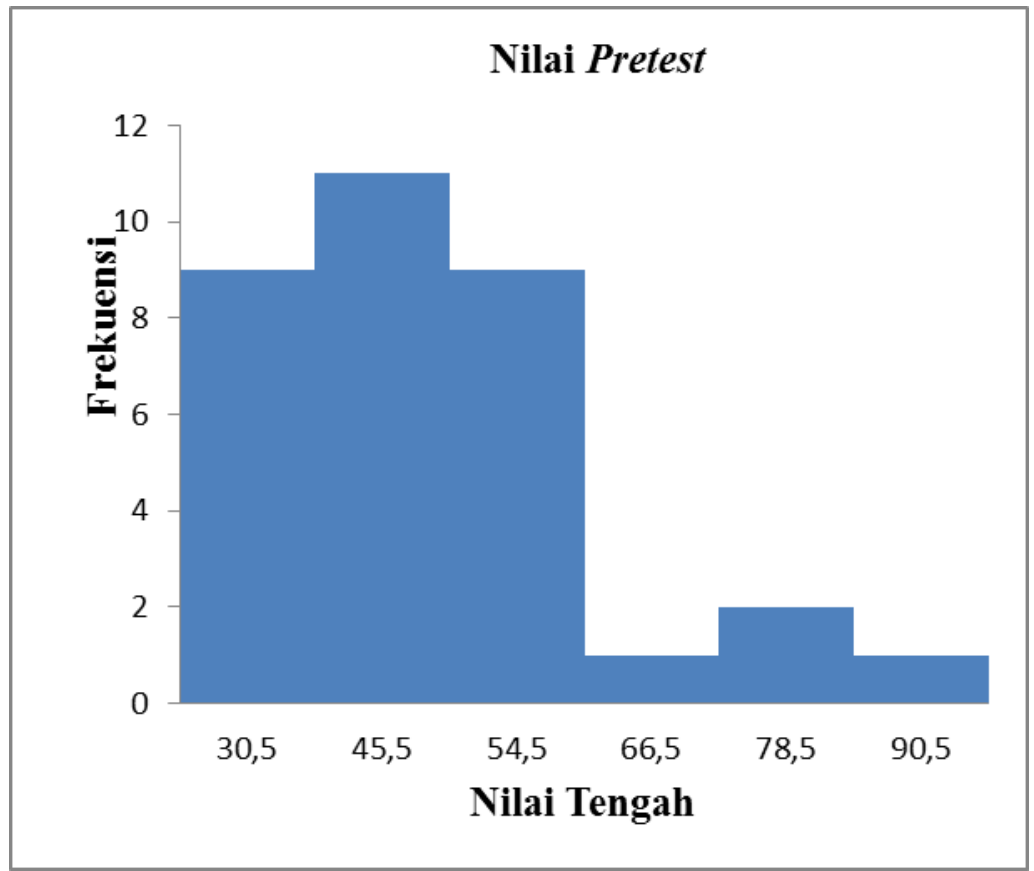

Gambar 6. Diagram Nilai Pretest

b. Kemampuan teknik dasar tendangan lurus saat Posttest.

Tabel 2. Deskripsi Data Posttest

\begin{tabular}{cc}
\hline $\mathrm{N}$ & 33 \\
\hline Mean & 63.90 \\
Median & 62,5 \\
Std. Deviation & 17,63 \\
Variance & 310,81 \\
Minimum & 33 \\
Maximum & 100 \\
\hline
\end{tabular}

Hasil perhitungan dari data tes kemampuan teknik dasar tendangan lurus siswa kelas VII SMP Negeri 2 Pangkalpinang saat posttest diperoleh hasil data Mean 63.90, Median 62,5, Std.Deviation 17,63, Variance 310,81, Minimum 33, Maksimum 100.

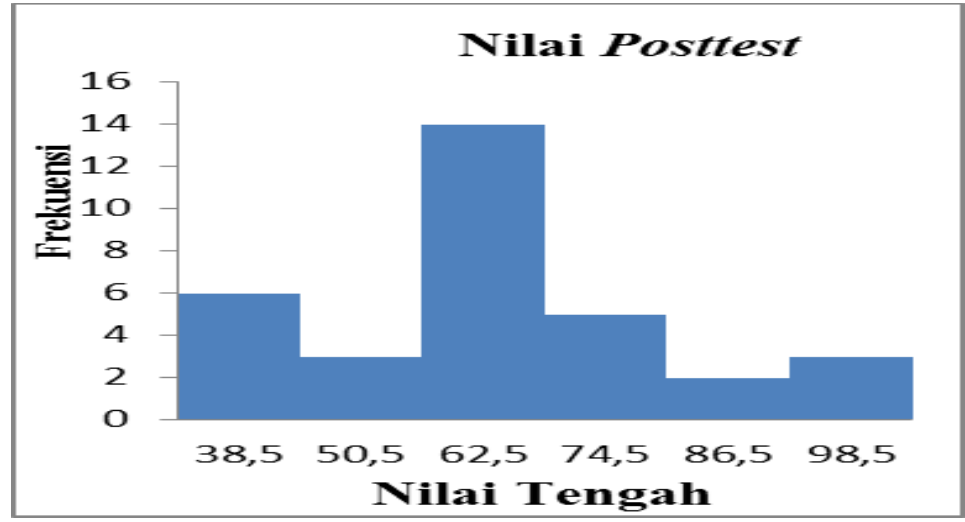

Gambar 7. Diagram Nilai Postttest 
c. Grafik Perbandingan Nilai Rata-Rata Pretest dan Posttest.

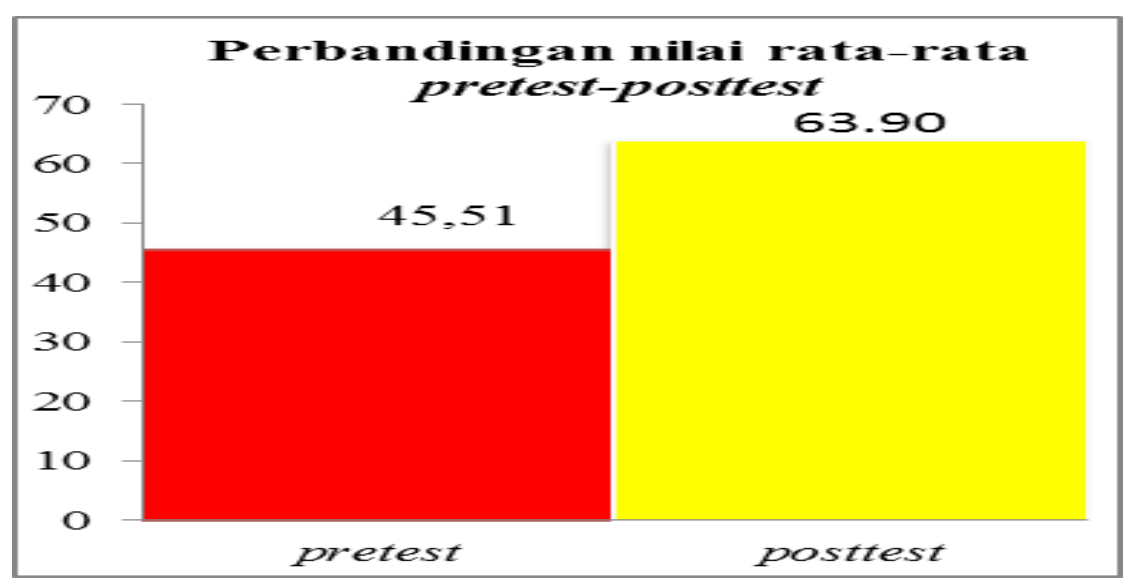

Gambar 8. Diagram Perbandingan nilai rata-rata pretest-posttest

Grafik perbandingan kedua test ini dibentuk dari hasil uji masing-masing test. Pada nilai test awal (pretest) diperoleh nilai rata-rata 45.51 dan hasil tes akhir (postest) diperoleh nilai rata-rata 63.90. Pada uji normalitas nilai test awal (pretest) diperoleh hasil 0.234 sedangkan terakhir (postest) diperoleh hasil 0.126 .

\section{Persyaratan analisis data}

a. Uji Normalitas. Untuk Uji normalitas dapat dilihat pada tabel 3.

Tabel 3. Uji Normalitas

\begin{tabular}{|c|c|c|c|}
\hline \multirow[t]{2}{*}{ Data } & \multicolumn{2}{|c|}{ Kolmogrov-smirnov } & \multirow[t]{2}{*}{ Ket } \\
\hline & $D_{\text {hitung }}$ & $D_{\text {tabel }}$ & \\
\hline Pretest & 0,234 & 0,2077 & Normal \\
\hline Posttest & 0,126 & 0,2077 & Normal \\
\hline
\end{tabular}

Berdasarkan tabel diatas, terlihat nilai pretest $\mathrm{D}_{\text {hitung }} 0,234$ dan posttest $D_{\text {hitung }} 0,126$ sedangkan nilai $D_{\text {tabel }} 0,2077$. Dari kedua kelompok data memiliki nilai $\leq$ $D_{\text {tabeel }}$ sehingga kedua kelompok dataa tersebut dikatakan berdistribusi normal.

b. Uji Homogenitas

Perhitungan uji homogenitas dilakukan menggunakan uji Fisher dengan berdasarkan $F_{\text {tabel. }}$ Jika $F_{\text {hitung }}<F_{\text {tabel }}$ maka data homogen, jika $F_{\text {hitung }}>F_{\text {tabel }}$ maka data tidak homogen.

Tabel 4. Rekapitulasi Hasil Uji Homogenitas

\begin{tabular}{cccc}
\hline Kelompok & $\mathrm{F}_{\text {hitung }}$ & $\mathrm{F}_{\text {tabel }}$ & Keterangan \\
\hline Pretest-Posttest & 1.27 & 1.80 & Homogen \\
\hline
\end{tabular}


Berdasarkan tabel di atas diperoleh nilai $F_{\text {hitung }} 1.27$ dan nilai $F_{\text {tabel }} 1.80 . F_{\text {hitung }}$ $1.27<\mathrm{F}_{\text {tabel } 1} 1.80$. Maka dapat disimpulkan bahwa penelitian ini memiliki varian yang homogen.

\section{c. UjiHipotesis}

Pengujian hipotesis dilakukan untuk mengetahui apakah ada pengaruh media Piramida terhadap kemampuan teknik dasar tendangan lurus pada siswa kelas VII SMP Negeri 2 Pangkalpinang.

Tabel 5. HasilUjiHipotesis

\begin{tabular}{lcccc}
\hline \multirow{2}{*}{ Variabel } & \multicolumn{3}{c}{ Uji-t } & Keterangan \\
\cline { 2 - 4 } & $\mathbf{t}_{\text {hitung }}$ & $\mathbf{t}_{\text {tabel }}$ & $\mathbf{D f}$ & \\
\hline 18,173 & 2.0423 & 33 & Berpengaruh
\end{tabular}

Berdasarkan tabel di atas, diperoleh $t_{\text {hitung }} 18,173$ dan $t_{\text {tabel }}$ 2.0423. Ternyata nilai $t_{\text {hitung }}$ lebih besar dari $\mathrm{t}_{\text {tabel }}(18.173>2.0423)$ maka $\mathrm{H}_{0}$ dan $\mathrm{H}_{\mathrm{a}}$ diterima sehingga dapat disimpulkan bahwa penelitian yang berjudul "pengaruh media piramida terhadap kemampuan teknik dasar tendangan lurus pada materi bela diri pencak silat siswa kelas VII SMP Negeri 2 Pangkalpinang" terdapat peningkatan sebesar 42\%.

Penelitian ini dilaksanakan pada 13-24 Januari semester genap tahun 2019/2020, dengan menggunakan sampel penelitian yaitu siswa kelas VII/C SMP Negeri 2 Pangkalpinang yang berjumlah 33 orang. Penelitian ini dilakukan selama 4 kali pertemuan, yaitu pada pertemuan pertama peneliti melakukan penilaian pretest teknik dasar tendangan lurus terhadap sampel penelitian untuk mengetahui kemampuan awal siswa sebelum diberikan treatment, pada pertemuan 2-3 peneliti memberikan perlakuan atau treatment dengan menggunakan media piramida Pertemuan ke 4 peneliti melakukan penilaian posttest untuk melihat pencapaian nilai pada kemampuan teknik dasar tendangan lurus pada materi bela diri pencak silat siswa kelas VII SMP Negeri 2 Pangkalpinang setelah diberikan treatment atau perlakuan.

Setelah semua data dianalisis dengan berbagai tahapan yang dimulai dengan uji statistika untuk menentukan mean, median, modus, standar deviasi, varian dan range. Kemudian dilakukan uji normalitas data untuk mengetahui apakah data hasil tersebut untuk keseluruhan nilai yang diperoleh setelah dilakukan perhitungan menyatakan bahwa semua data berdistribusi normal. Setelah data telah dinyatakan normal maka dapat dilakukan analisis terakhir. Analisis terakhir yang dilakukan adalah uji hipotesis dengan syarat Jika nilai $t_{\text {hitung }}<t_{\text {tabel }}$ maka $\mathrm{H}_{0}$ diterima dan $\mathrm{H}_{\mathrm{a}}$ ditolak dan Jika nilai $t_{\text {nitung }}>t_{\text {tabel }}$ maka $\mathrm{H}_{0}$ ditolak dan $\mathrm{H}_{\mathrm{a}}$ diterima Hasil yang diperoleh yaitu, $\mathrm{t}_{\text {hitung }} 18,173>\mathrm{t}_{\text {tabel }} 2.0423$ yang berarti $\mathrm{H}_{0}$ ditolak dan $\mathrm{H}_{\mathrm{a}}$ diterima. Maka dapat dinyatakan bahwa terdapat pengaruh dari media piramida terhadap kemampuan Teknik Dasar Tendangan Lurus Pada Materi Bela Diri Pencak Silat Siswa Kelas VII SMP Negeri 2 Pangkalpinang". Dengan media piramida dapat meningkatkan teknik dasar tendangan lurus (Ningtyas, R. R., 2019). Dengan konsentrasi dapat 
meningkatkan kecepatan tendangan pada pencak silat (Ihsan, N., \& Suwirman, S., 2018). Instrumen kecepatan berbasis teknologi dapat meningkatkan kecepatan tendangan lurus (Ihsan, N., Yulkifli, Y., \& Yohandri, Y.,2018). Teknik yang tepat akan meningkatkan kualitas (Saputra, A., Muzaffar, A., Alpaizin, M., \& Wibowo, Y. G., 2019). Dengan media yang variasi akan mampu meningkatkan peforma atlet (Anto,A.H., 2019). Media dapat meningkatkan hasil belajar siswa (Aina, M., 2016;Sadikin, A., 2018). Media adalah alat untuk menyampaikan informasi yang membantu penjelasan guru. Media tidak terpisah dalam pembelajaran di sekolah (Sholichah, L. A. M., \& Sukidi, M., 2011; Arifudin, A., Kuswandi, D., \& Soepriyanto, Y., 2019). Pengembangan produk pembelajaran membantu kecakapan peserta didik (Handoko, A. H., \& Pandiangan, D. S., 2019)

\section{KESIMPULAN}

Berdasarkan hasil anaalisis data dan pembahasan yang dikemukakan pada bab IV. Diperoleh hasil uji normalitas menggunakan rumus Kolmogrov-smirnov diperoleh hasil pretest 0,234 dan hasil posttest 0,126 , sedangkan $D_{\text {tabel }} 0,2077$ maka kedua kelompok data memiliki nilai $\leq D_{\text {tabel }}$ sehingga kedua kelompok data tersebut dikatakan berdistribusi normal. Kemudian setelah data berdistribusi normal dilakukan uji homogenitas menggunakan Uji-Fisher diperoleh hasil nilai $F_{\text {hitung }} 1.27$ dan nilai $F_{\text {tabel }} 1.80$. $F_{\text {hitung }} 1.27<\mathrm{F}_{\text {tabel }} 1.80$, maka dapat disimpulkan bahwa kelas eksperimen memiliki varian yang homogen. Pengujian terakhir yaitu pada uji hipotesis terdapat peningkatan sebesar $42 \%$ dengan menggunakan Uji-t diperoleh nilai $t_{\text {hitung }}$ lebih besar dari $t_{\text {tabel }}(18,173>2.0423)$ dengan taraf signifikan 0,05 maka $\mathrm{H}_{0}$ ditolak dan $\mathrm{H}_{\mathrm{a}}$ diterima sehingga dapat disimpulkan bahwa penelitian yang berjudul "pengaruh media piramida terhadap kemampuan teknik dasar tendangan lurus pada materi bela diri pencak silat siswa kelas VII SMP Negeri 2 Pangkalpinang" terdapat pengaruh yang signifikan.

\section{DAFTAR PUSTAKA}

Anitah Sri. (2014). Strategi Pembelajaran Di SD. Tanggerang Selatan: Universitas Terbuka.

Andari, M. S. (2014). Peningkatan Kemampuan Berbahasa Anak Kelompok Bermain

Di Kb/Ba Restu 1 Kota Malang Melalui Media Piramida Cerita. SKRIPSI Jurusan Kependidikan Sekolah Dasar \& Prasekolah-Fakultas IImu Pendidikan UM.

Aina, M. (2016). Pengembangan Multimedia Interaktif Menggunakan Camtasia Studio 8 Pada Pembelajaran Biologi Materi Kultur Jaringan Untuk Siswa SMA Kelas XI MIA. Biodik, 2(1).

Amran .(2010). Menguak Rumpun Pencak Silat Minangkabau. Pekan Baru: Sutera Benta Perkasa.

Anto,A.H. (2019). PENGARUH VARIASI LATIHAN SINGLE LEG JUMP TERHADAP PENINGKATAN HASIL LOMPAT JAUH SISWA SMP ISLAM AL-FALAH KOTA JAMBI. Indonesian Journal Of Sport Science And 
Coaching, 1(2), 75-80.

Ali Maksum. (2012). Metodologi Penelitian Dalam Olahraga. Semarang: Unesa University Press.

Agus Widodo. (2012). 'Persepsi Pelajar Terhadap Pencak Silat Sebagai Warisan Budaya Bangsa Sekota Semarang Tahun 2012'. Journal Of Physical Education, Sport, Health And Recreations. 1 (3). HIm. 1-135.

Arifudin, A., Kuswandi, D., \& Soepriyanto, Y. (2019). Pengembangan Media Obyek 3

Dimensi Digital Sel Hewan dan Tumbuhan Memanfaatkan Piramida Hologram Untuk MTS. Jurnal Kajian Teknologi Pendidikan, 2(1), 9-15.

Arsyad Azhar. (2017). Media Pembelajaran. Jakarta: Rajawali Pers.

Badru Zaman, (2012). Media Dan Sumber Belajar TK. Banten: Universitas Terbuka.

Bangun, S. Y. (2016). Peran Pendidikan Jasmani Dan Olahraga Pada Lembaga Pendidikandi Indonesia. Publikasi Pendidikan, 6(3).

Daryanto. (2013). Media Pembelajaran. Yogyakarta: Gava Media.

Erwin Setyo Kriswanto. (2015). Pencak Silat. Yogyakarta: Pustaka Baru Press.

Edi Riadi. (2014). Metode Statistik Parametrik Dan Non Parametrik. Tangerang: PT Pustaka Mandiri.

Eddy Purnomo. (2007). Gerak Dasar Atletik. Universitas Negeri Yogyakarta.

Filipus, W. (2019). Pengembangan Modelteknik Egosan Dengan Tendangan Lurus Pada Pencak Silat (Doctoral Dissertation, UNIMED).

Hamid Darmadi. (2014). Metode Penelitian Pendidikan Dan Sosial. Bandung: Alfabeta.

Handoko, A. H., \& Pandiangan, D. S. (2019). PENGEMBANGAN PAPAN TUMPUAN

DALAM PEMBELAJARAN LOMPAT JAUH. Indonesian Journal Of Sport Science And Coaching, 1(2), 65-74.

Haryani Nasution. (2017). Buku Pintar Pencak Silat. Jakarta: Anugerah.

Ihsan, N., \& Suwirman, S. (2018). Sumbangan Konsentrasi Terhadap Kecepatan Tendangan Pencak Silat. Media IImu Keolahragaan Indonesia, 8(1), 1-6.

Ihsan, N., Yulkifli, Y., \& Yohandri, Y. (2018). Instrumen Kecepatan Tendangan Pencak Silat Berbasis Teknologi. Jurnal Sosioteknologi, 17(1), 124-131.

I Made Sukardi. (1983). Bimbingan Penyuluhan. Surabaya: Usaha Nasional.

Johansyah Lubis Dan Hendro Wardoyo. (2016). Pencak Silat Edisi Ketiga. Jakarta:

Raja Grafindo Persada.

Joyce, B., Marsha Weil And Emily Calhoun. (2000). Models Of Teaching. Boston:

Allyn And Bacon Edisi Ke-6.

M.Said Hasan. (2015). 'Hubungan Antara Panjang Tungkai, Keseimbangan Dan

Kekuatan Otot Tungkai Terhadap Kemampuan Tendangan Depan Pada

Cabang Olahraga Pencak Silat Mahasiswa FIK UNM'. Jurnal Ilara. VI (2), HIm. 1-74.

Mila Mardotillah. (2016). Identitas Budaya, Pendidikan, Seni Bela Diri, Dan

Pemeliharaan Kesehatan'. Jurnal Antropologi. 18 (2). HIm. 121-133.

Murniasari. (2008). Atletik. Jakarta: Ganeka.

Ningtyas, R. R. (2019). Efektivitas Latihan Power Tungkai Menggunakan Media Untuk Meningkatkan Kecepatan Tendangan Mawashi Geri Pada Atlet Karate 
Aka Inazuma Training Camp Bandar Lampung.

Nugraha, B. E. (2014). Analisis Kecepatan Tendangan Pencak Silat Pada Pesilat Unit Kegiatan Mahasiswa Universitas Mulawarman. Samarinda: Universitas Mulawarman.

Pardjono, Dkk. (2007). Panduan Penelitian Tindakan Kelas. Yogyakarta: Lembaga Penelitian Universitas Negeri Yogyakarta.

Rosdiani. (2013). Perencanaan Pembelajaran Dalam Penjaskes. Bandung: Alfabeta.

Royana, I. F. (2017). Pelestarian Kebudayaan Nasional Melalui Permainan Tradisional Dalam Pendidikan Jasmani. In Seminar Nasional Keindonesiaan II Tahun 2017 "Strategi Kebudayaan Dan Tantangan Ketahanan Nasional Kontemporer, FPIPSKR Universitas PGRI Semarang (Pp. 1-11). Universitas PGRI Semarang.

Rusli Lutan. (2004). Strategi Pembelajaran Penjas. Jakarta: Universitas Terbuka. Saeful Azwar. (2000) Strategi Belajar Mengajar. Jakarta Universitas Terbuka.

Sadikin, A. (2018). Penerapan Jurnal Belajar Untuk Meningkatkan Motivasi Belajar Mahasiswa Pada Mata Kuliah Dasar-Dasar Dan Proses Pembelajaran Biologi. Bioeducation Journal, 2(1), 70-75.

Saputra, A., Muzaffar, A., Alpaizin, M., \& Wibowo, Y. G. (2019). ANALISIS KEMAMPUAN TEKNIK DASAR PEMAIN SEPAK BOLA SSB PRATAMA KABUPATEN BATANGHARI. Indonesian Journal Of Sport Science And Coaching, 1(1), 1-10.

Sugiyono. (2017). Metode Penelitian Kuantitatif, Kulitatif, Dan R\&D. Bandung: Alfabeta.

Sudijono. (2015). Pengantar Evaluasi Pendidikan. Jakarta: PT Raja Grafindo Persada.

Sucipto. (2001). Pendekatan Keterampilan Taktis Dalam Pembelajaran Pencak Silat. Jakarta Pusat: Dirjen Olahraga.

Steffi Adam. (2015). Pemanfaatan Media Pembelajaran Berbasis Teknologi Informasi Bagi Siswa Kelas X SMA Ananda Batam'. Jurnal CBIS. 3 (2). HIm. (1-13).

Sajoto. (1988). Peningkatan Dan Pembinaan Kekuatan Kondis Fisik Dalam Olahraga, Semarang, Dahara Prize.

Sholichah, L. A. M., \& Sukidi, M. (2011). Efektivitas Penggunaan Media Pembelajaran Piramida Cerita Terhadap Keterampilan Menulis Narasi Siswa Sekolah Dasar. Jurnal Penelitian Pendidikan Guru Sekolah Dasar, 3(2).

Soetoto Pontjopoetro. (2002).Lompat Tali. (Http://Indoshvong. Blogspot.

Com/2010//). Diunduh Pada Tanggal 12 September 2014.

Subagiyo, Dkk. (2003). Perencanaan Pembelajaran Penjas. Jakarta: Universitas Terbuka.

Suharsimi Arikunto. (2002). Penelitian Suatu Pendekatan Praktik. Jakarta: PT. Rineka Cipta.

Sumadi Suryabrata. (2002). Belajar Dan Pembelajaran. Jakarta: Rajawali Pers. Syaiful Bahri. (1994). Strategi Pembelajaran. Jakarta: Depdiknas.

Tim Abdi Guru. (2006). Pendidikan Jasmani Dan Kesehatan Kelas IV. Erlangga. 
Udin S Winataputra, M.A., Dkk. (2004). Strategi Belajar Mengajar. Jakarta: Universitas Terbuka.

Wilujeng, F. (2011). Penerapan Media Piramida Cerita unuk Meningkatkan Keterampilan Menulis Siswa SDN Pagentan 05 Singosari. Tugas Akhir Jurusan Kependidikan Sekolah Dasar \& Prasekolah-Fakultas IImu Pendidikan UM.

Yudha M. Saputra. (2001). Teori Bermain. Jakarta. Depdiknas.

Yuliantika, S. (2017). Pengembangan Media Piramida Cerdas Pada Pembelajaran Tematik Tema Cita-Citaku Untuk Siswa Kelas IV SD (Doctoral dissertation, University of Muhammadiyah Malang). 